\title{
PROBLEMATYKA BADAWCZA Z ZAKRESU POCZUCIA BEZPIECZEŃSTWA CZLOWIEKA W PRZESTRZENI MIASTA
}

\begin{abstract}
Zarys treści Praca ma charakter przeglądowy i dotyczy polskich publikacji podejmujących problematykę poczucia bezpieczeństwa człowieka w przestrzeni miasta. Analizowano następujące zagadnienia: 1) dobre i złe dzielnice jako stereotypy przestrzenne, 2) poczucie bezpieczeństwa a typ zabudowy, 3) poczucie bezpieczeństwa w miejscach publicznych, 4) poczucie bezpieczeństwa w sąsiedztwie, 5) poczucie bezpieczeństwa a pora dnia oraz 6) poczucie bezpieczeństwa a cechy demograficzno-społeczne.
\end{abstract}

Słowa kluczowe Poczucie bezpieczeństwa, geografia przestępczości, miasto, Polska.

\section{Wprowadzenie}

Celem artykułu jest przedstawienie problematyki badawczej z zakresu poczucia bezpieczeństwa człowieka w przestrzeni miasta. Opracowanie rozpoczęto od wyróżnienia kierunków badań geografii przestępczości oraz zdefiniowania pojęcia poczucia bezpieczeństwa. Następnie dokonano przeglądu wybranych polskich publikacji z zakresu poczucia bezpieczeństwa człowieka w przestrzeni miasta oraz przedstawiono wybrane wyniki badań.

W geografii przestępczości wyróżnia się dwa kierunki badań. Pierwszy związany jest $\mathrm{z}$ analizami zróżnicowania i dynamiki przestępczości w różnych skalach przestrzennych, np. w regionach i miastach oraz identyfikacją miejsc szczególnie zagrożonych przestępczością. Wykorzystuje się do tego „obiektywne” dane statystyczne z policji. Drugi kierunek dotyczy badań nad postrzeganiem przestępczości i strachem przed nią, a więc bazuje na „subiektywnych” informacjach, pochodzących najczęściej z badań ankietowych mieszkańców (Maik 1995; Czyż 1996).

Wzrost zainteresowania badaniami nad strachem przed przestępczością (fear of crime), nie tylko w literaturze naukowej, ale również w mediach i polityce różnych szczebli, nastąpił pod koniec XX wieku (Pain 2000). Badania te są o tyle istotne, że poczucie zagrożenia wyłaniające się w opinii publicznej nie 
zawsze pokrywa się z obrazem przestępczości wynikającym z policyjnych danych statystycznych (Frieske 2007). Warto podkreślić, że badania ankietowe dotyczące przestępczości posiadają duże znaczenie w planowaniu działań prewencyjnych (Tseloni i in. 2002), realizacja których przekłada się na realny wzrost bezpieczeństwa ludzi.

Pojęcie poczucia bezpieczeństwa można rozpatrywać $\mathrm{w}$ dwóch ujęciach. W ujęciu socjologicznym, bezpieczeństwo jest zobiektywizowanym stanem braku zagrożenia, integralnie związanym z subiektywnym, emocjonalnym, psychologicznym odbieraniem przestrzeni jako bezpiecznej, inaczej poczuciem bezpieczeństwa (Czarnecki, Siemiński 2004). W ujęciu prawnym to „(...) ogół warunków i instytucji społecznych, chroniących państwo i obywateli przed zjawiskami groźnymi dla ładu prawnego, dla życia i zdrowia, a także powodującymi duże straty materialne. Do zapewnienia bezpieczeństwa publicznego zobowiązane są wszystkie organy władzy i administracji państwowej, szczególnie instytucje wyspecjalizowane w zapewnianiu bezpieczeństwa publicznego, jak np. policja, straż pożarna itp." (Jabkowski 2005: 135).

\section{Przegląd wybranych publikacji z zakresu poczucia bezpieczeństwa czlowieka w przestrzeni miasta}

W polskim dorobku geografii przestępczości ważne miejsce zajmują prace dotyczące postrzegania przestępczości przez mieszkańców miast (Bogacka 2011, 2012). Opracowania wykorzystujące „subiektywne” wskaźniki są dominującym kierunkiem tej subdyscypliny geografii społecznej w Polsce. Charakterystykę wybranych polskich publikacji z zakresu poczucia bezpieczeństwa człowieka w mieście przedstawiono w tabeli 1. Dominują w nich publikacje z dwóch ośrodków: łódzkiego i poznańskiego. Liczebność prób w badaniach ankietowych była zróżnicowana: od 100 (Mordwa 2011) do 5342 (Rydz, Szymańska 2007). W podejściu badaczy do miejsc ankietowania mieszkańców można zauważyć zasadniczo dwie tendencje. Badania przeprowadzane były w: 1) wyznaczonych obszarach miasta o zróżnicowanym typie zabudowy, np. zabudowa kamieniczna, wielorodzinna, jednorodzinna (Guzik 2000ab; Dolata, Kotus 2004, 2006; Kotus 2005; Mordwa 2011, 2013), 2) mieście traktowanym jako całość, z uwzględnieniem proporcjonalnej do liczby mieszkańców udziału każdej z dzielnic (Marcińczak, Siejkowska 2003; Jabkowski 2005; Rydz, Szymańska 2007; Bogacka 2009, 2012; Bogacka, Siniecka 2016). Zakres badań był zróżnicowany: od oceny fragmentów miasta pod względem bezpieczeństwa (Rydz, Szymańska 2007) po bardzo szczegółowe oceny bezpieczeństwa za dnia i w nocy w: mieście, miejscu zamieszkania, miejscach publicznych. 


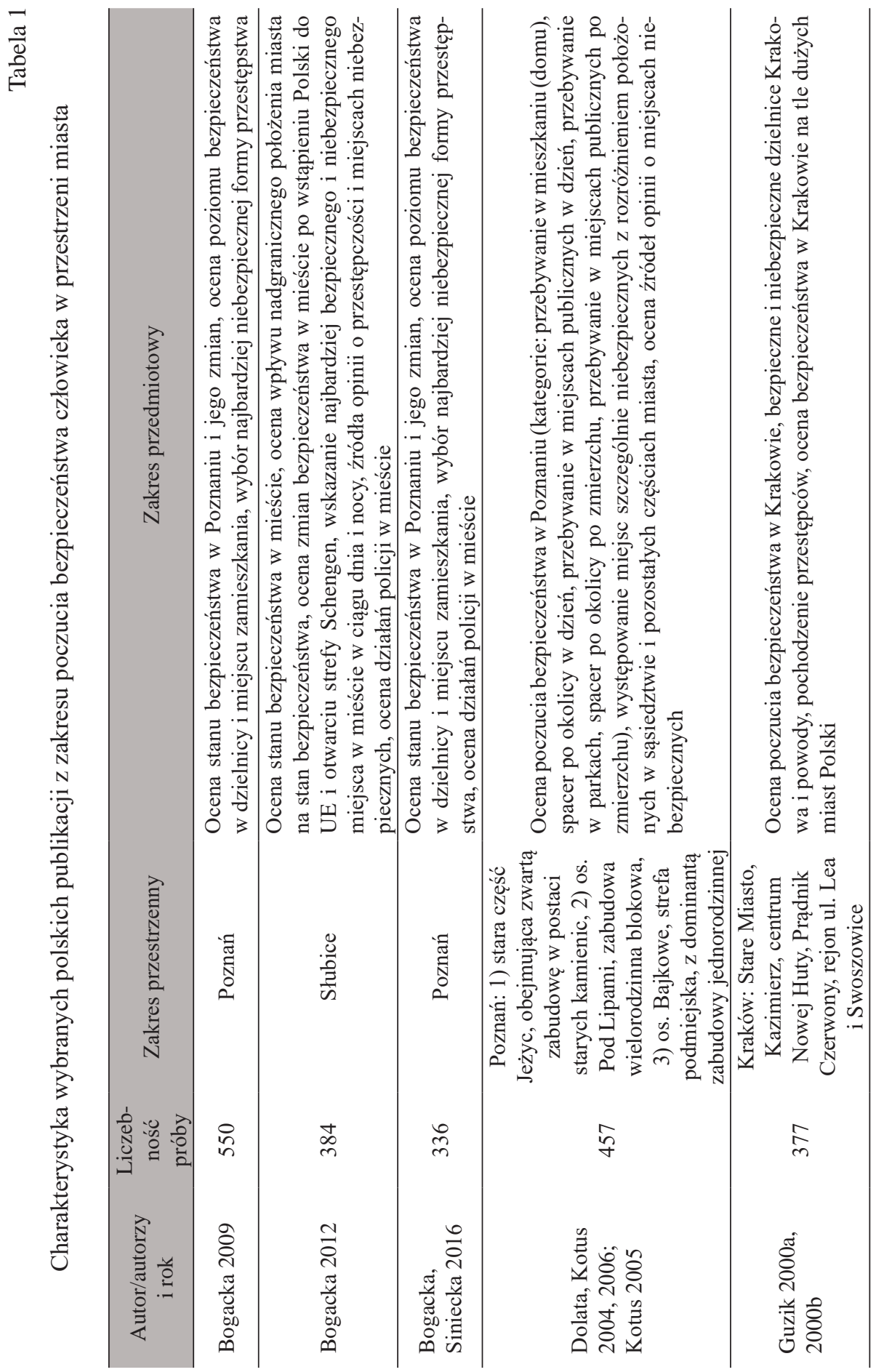




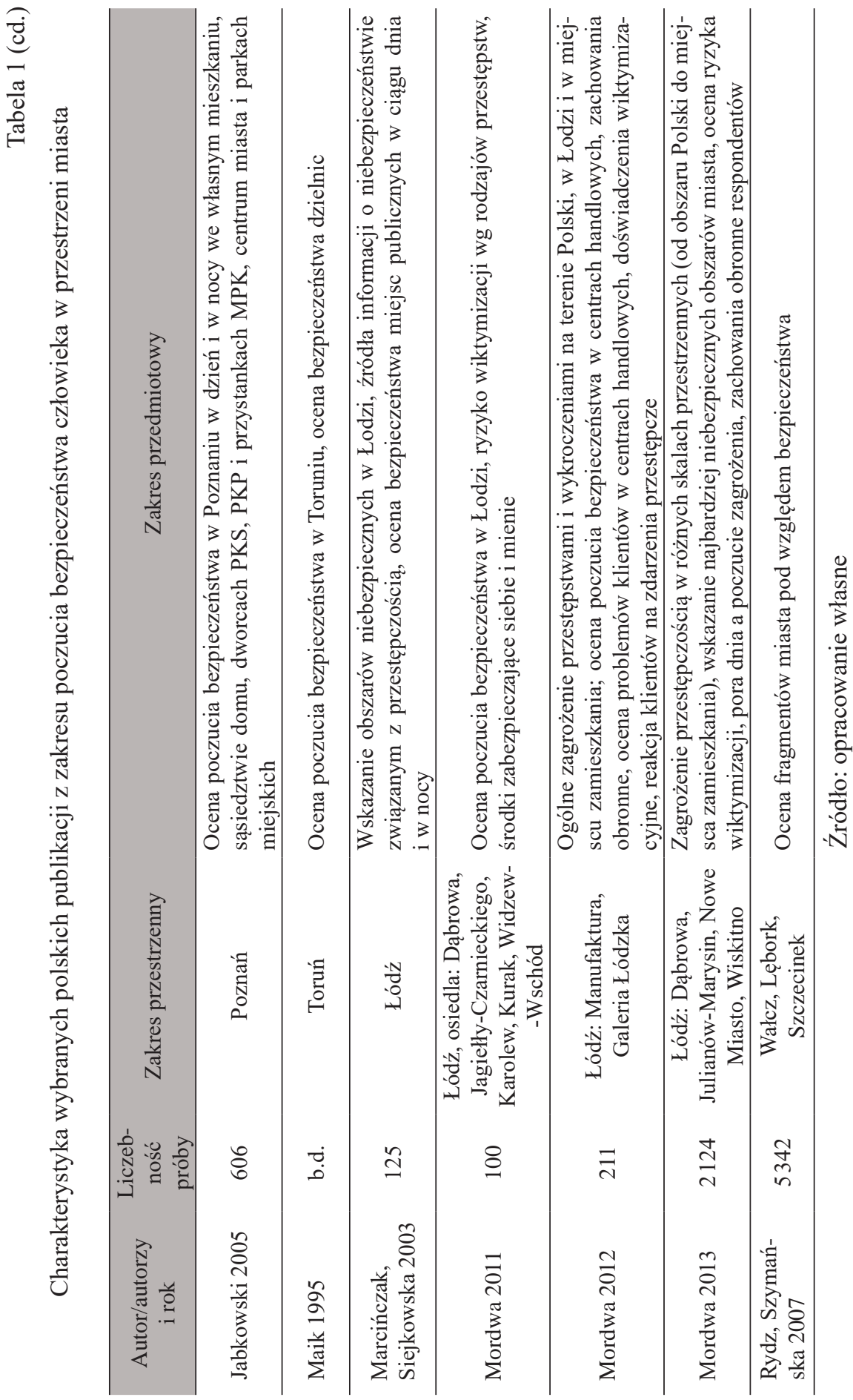




\section{Wybrane wyniki badań poczucia bezpieczeństwa czlowieka w przestrzeni miasta}

W pracy skoncentrowano się na wybranych wynikach badań poczucia bezpieczeństwa człowieka w przestrzeni miasta. Poruszono następujące zagadnienia: 1) dobre i złe dzielnice jako stereotypy przestrzenne, 2) poczucie bezpieczeństwa a typ zabudowy, 3) poczucie bezpieczeństwa w miejscach publicznych, 4) poczucie bezpieczeństwa w sąsiedztwie, 5) poczucie bezpieczeństwa a pora dnia, 6) poczucie bezpieczeństwa a cechy demograficzno-społeczne. Autorka ma świadomość, że każde z tych zagadnień mogłoby stanowić temat odrębnych publikacji.

\section{Dobre i zle dzielnice - stereotypy przestrzenne}

W literaturze badacze często operują pojęciami dobrej i złej dzielnicy. Dzielnica, czy też jej część, mogą zostać uznane za spokojne, bezpieczne, interesujące lub na odwrót, za niespokojne, niebezpieczne, nieciekawe. Przestępczość jest zjawiskiem dzielącym przestrzeń na jej „lepsze” i „gorsze” fragmenty, dzielnice bezpieczne i o złej reputacji, w których ludność nie chce mieszkać, ani pracować (Guzik 2000b). Często opinia o danym fragmencie miasta jest silnie zakorzeniona w świadomości mieszkańców, przekazywana z pokolenia na pokolenie, tym samym stając się stereotypową. W każdym mieście istnieją utrwalone wyobrażenia mieszkańców o miejscach niebezpiecznych, tyle tylko, że obraz ten nie zawsze w pełni pokrywa się z obszarami o największej liczbie lub natężeniu przestępstw (Mordwa 2013).

W Poznaniu istnieją dość silne stereotypy przestrzenne, utrzymujące się od wielu lat (tab. 2). Zasadniczo Wilda uznawana jest za najbardziej niebezpieczną dzielnicę. Negatywny sposób postrzegania poszczególnych dzielnic w Poznaniu może być wyjaśniony koncepcją stygmatyzacji, zgodnie z którą opinia o niektórych miejscach jest wyolbrzymiona w stosunku do rzeczywistości (Dolata i Kotus 2004). Sytuacja ta może powstać, jeśli „w wyniku pewnego zdarzenia - jego miejsce (osiedle, sąsiedztwo) zdobywa złą opinię i każde następne zdarzenie jest tam nagłaśniane. (...) Dodatkowo w takim obszarze działania policji są bardziej wzmożone, gdyż jest to obszar ,trudny”, w efekcie stwierdza się tam więcej przestępstw niż w innych dzielnicach" (Guzik 2000b). Pewien wpływ na postrzeganie dzielnicy może mieć również jej obraz kształtowany w prasie (Guzik 2000b; Bogacka 2009).

\section{Poczucie bezpieczeństwa a typ zabudowy}

Ocena bezpieczeństwa wybranych obszarów wykazuje zróżnicowanie w zależności od miejsca zamieszkania (Maik 1995). Zasadniczo obszary położone relatywnie dalej od centrum są uważane za bardziej bezpieczne, a wpływ na to ma głównie charakter zabudowy i zamieszkująca społeczność (Marcińczak, Siejkowska 
Wybrane publikacje dotyczące poczucia bezpieczeństwa w Poznaniu w układzie dzielnicowym

\begin{tabular}{|c|c|c|}
\hline \multirow{2}{*}{$\begin{array}{l}\text { Autor/autorzy } \\
\text { i rok }\end{array}$} & \multicolumn{2}{|c|}{ Najczęściej wskazywane obszary } \\
\hline & $\begin{array}{c}\text { Niebezpieczne } \\
\text { tzw. ,złe dzielnice” }\end{array}$ & $\begin{array}{c}\text { Bezpieczne } \\
\text { tzw. „dobre dzielnice” }\end{array}$ \\
\hline $\begin{array}{l}\text { Znaniecki, Ziółkowski } \\
1984\end{array}$ & brak & $\begin{array}{l}\text { Grunwald } \\
\text { Stare Miasto z Ostrowem } \\
\text { Tumskim }\end{array}$ \\
\hline Biderman 1995 & $\begin{array}{l}\text { Wilda } \\
\text { Jeżyce } \\
\text { Łazarz }\end{array}$ & $\begin{array}{l}\text { Grunwald } \\
\text { Winogrady } \\
\text { Sołacz }\end{array}$ \\
\hline Libura 1990 & $\begin{array}{l}\text { Wilda } \\
\text { Łazarz } \\
\text { Dębiec }\end{array}$ & $\begin{array}{l}\text { Grunwald } \\
\text { Stare Miasto } \\
\text { Winogrady }\end{array}$ \\
\hline $\begin{array}{l}\text { Cichocki, Podemski } \\
1998\end{array}$ & $\begin{array}{l}\text { Wilda } \\
\text { Stary Rynek } \\
\text { Łazarz (rynek) } \\
\text { Jeżyce (rynek) }\end{array}$ & brak \\
\hline Jałowiecki 2000 & $\begin{array}{l}\text { Wilda } \\
\text { Jeżyce } \\
\text { Łazarz }\end{array}$ & $\begin{array}{l}\text { Grunwald } \\
\text { Sołacz } \\
\text { Piątkowo }\end{array}$ \\
\hline Dolata, Kotus 2006 & $\begin{array}{l}\text { Wilda } \\
\text { Jeżyce } \\
\text { Stare Miasto } \\
\text { Łazarz } \\
\end{array}$ & brak \\
\hline Bogacka 2009 & $\begin{array}{l}\text { Wilda } \\
\text { Jeżyce } \\
\end{array}$ & $\begin{array}{l}\text { Grunwald } \\
\text { Nowe Miasto }\end{array}$ \\
\hline $\begin{array}{l}\text { Bogacka, Siniecka } \\
2016\end{array}$ & $\begin{array}{l}\text { Wilda } \\
\text { Jeżyce }\end{array}$ & $\begin{array}{l}\text { Nowe Miasto } \\
\text { Stare Miasto } \\
\text { Grunwald } \\
\end{array}$ \\
\hline $\begin{array}{l}\text { Walentynowicz- } \\
\text {-Moryl, Luczys } 2012\end{array}$ & $\begin{array}{l}\text { Wilda } \\
\text { Jeżyce } \\
\text { Dębiec }\end{array}$ & $\begin{array}{l}\text { Starówka } \\
\text { Św. Marcin } \\
\text { Maltańskie } \\
\end{array}$ \\
\hline
\end{tabular}

Źródło: opracowanie własne na podstawie: K. Piasecka (2015)

2003). Cechą charakterystyczną wszystkich publikacji jest zdecydowana koncentracja na obszarach uważanych za niebezpieczne. Mało miejsca poświęca się obszarom bezpiecznym.

Ogólne wyobrażenie o przestępczości jest takie, że jest ona niska tam, gdzie przeważają domy jednorodzinne: w Krakowie - Swoszowice, Tyniec i Wola Justowska (Guzik 2000b), w Poznaniu - Antoninek, Spławie, Strzeszyn, 
Strzeszyn Grecki i Świerczewo (Bogacka 2009), w Wałczu - osiedle pomiędzy ul. Kołobrzeską a ul. Piłsudskiego (Rydz, Szymańska 2007).

Kategorią pośrednią są dzielnice uznawane w opinii mieszkańców za elitarne, z nowoczesnym lub zadbanym budownictwem wielorodzinnym, bez tzw. ,elementu" patologicznego, w Krakowie - Bronowice, Krowodrza (Guzik 2000b).

W Łodzi za szczególnie niebezpieczne uważane są tereny starej zabudowy czynszowej dzielnicy śródmiejskiej Łodzi oraz obszary o podobnej fizjonomii znajdujące się w sąsiadujących dzielnicach: okolice Rynku Bałuckiego i ul. Limanowskiego, ul. Żeromskiego i ul. Wólczańska na Polesiu, okolice Księżego Młyna na Widzewie (Marcińczak, Siejkowska 2003). Głównymi elementami decydującymi o unikaniu poszczególnych obszarów jest charakter zabudowy - kamienice czynszowe, wąskie ulice, przechodnie podwórka oraz blokowiska (Marcińczak, Siejkowska 2003). Niskie poczucie bezpieczeństwa na obszarze starej zabudowy czynszowej w Łodzi od Starych Bałut po Chojny potwierdzają również badania S. Mordwy (2013). Za niebezpieczne uznawane są również tereny osiedli z zabudową blokową, tj. Dąbrowy, Zarzewia i Widzewa Wschód (Mordwa 2013).

\section{Poczucie bezpieczeństwa w miejscach publicznych}

Miejsca publiczne stosunkowo często pojawiają się w badaniach poczucia bezpieczeństwa. W literaturze można znaleźć odwołania do terenów zielonych (parków), śródmieścia, dzielnicowych rynków pełniących funkcję handlową i terenów komunikacyjnych.

W Łodzi tereny zieleni przestają być wykorzystywane po zapadnięciu zmroku z powodu niskiego poczucia bezpieczeństwa (Marcińczak, Siejkowska 2003). Również niektóre parki Poznania, tj. Cytadela, Lasek Marceliński i Park Gagarina (os. Pod Lipami) są uznawane przez mieszkańców za niebezpieczne, mimo niskiego realnego zagrożenia (Dolata, Kotus 2004). Jak zauważa R. Guzik (2000b), ludność ma tendencje do odczuwania obawy w miejscach niekoniecznie najbardziej niebezpiecznych i czuje się bezpiecznie w miejscach, które są szczególnie zagrożone przestępczością.

Mieszkańcy bezpiecznie czują się w centrum miasta. Kwestia znajomości miejsca i częstotliwości jego odwiedzania wydaje się być kluczowa (Guzik 2000b). Tak jest przykładowo w Poznaniu, gdzie respondenci uważają ten obszar za znany, odwiedzają go z pewną regularnością, nie zauważając tam zjawiska przestępczości (Bogacka 2009). W Krakowie obszar Śródmieścia został uznany za bezpieczny, gdyż jest tam widoczna policja (Guzik 2000b). Badania E. Rydza i W. Szymańskiej (2007) w Szczecinku dostarczyły takich samych rezultatów.

Rynek Jeżycki, jeden z dzielnicowych rynków w Poznaniu, pełniący rolę centrum drobnego handlu ulicznego jest miejscem, gdzie mieszkańcy mają niskie poczucie bezpieczeństwa (Dolata, Kotus 2004). 
Podzielone są zdania dotyczące poczucia bezpieczeństwa w okolicach dworców PKP. Z badań R. Guzika (2000b) wynika, że mieszkańcy Krakowa mają małe obawy, z kolei z badań M. Dolaty i J. Kotusa (2004) w Poznaniu oraz E. Rydza i W. Szymańskiej (2007) w Lęborku i Wałczu odwrotnie.

\section{Poczucie bezpieczeństwa w sąsiedztwie}

Sąsiedztwo, obszar najbliższy miejscu zamieszkania, jest obszarem z jednoznacznie wysokim poczuciem bezpieczeństwa. Takie wyniki badań uzyskano w Łodzi, Krakowie i Poznaniu. Ludność podświadomie uznaje miejsce swojego zamieszkania za bezpieczne, czasem mimo potwierdzonej statystykami policyjnymi zupełnie odwrotnej sytuacji (Bogacka 2009, 2012) Podobnie kwestię ujmuje S. Mordwa (2013): „Miejsce zamieszkania jest raczej niezagrożone ze strony przestępstw i wykroczeń”. Jak zauważa R. Guzik (2000b), „Potwierdza to (...) dobrze znaną zasadę eliminacji zagrożenia poza własne sąsiedztwo”.

\section{Poczucie bezpieczeństwa a pora dnia}

Pora dnia ma duże znaczenie w kwestii poczucia bezpieczeństwa. Ocena jest uzależniona od pory dnia i odległości od miejsca zamieszkania, na co wskazują badania M. Dolaty i J. Kotusa (2004) oraz E. Bogackiej (2009). Zasadniczo człowiek czuje się bezpieczniej w ciągu dnia, szczególnie w przypadku poruszania się po najbliższej okolicy (Kotus 2005). Przykładowo mieszkańcy dużych osiedli blokowych uważają je za bezpieczne w ciągu dnia, a niebezpieczne w nocy (Marcińczak, Siejkowska 2003).

Największe zagrożenie odczuwane jest po zmierzchu i jest większe w miejscach publicznych niż w najbliższym otoczeniu (Dolata, Kotus 2004; Kotus 2005; Bogacka 2009). Z kolei S. Mordwa (2013) zwraca uwagę na to, że wychodzenie po zmroku z domu powoduje odczuwanie niebezpieczeństwa i może to być spowodowane zwiększoną możliwością bycia ofiarą napadu lub przykładowo wychodzeniem bez towarzystwa (drugiej osoby, grupy osób, psa). Obszary zagrożone przestępczością unikane są przede wszystkim w nocy (Marcińczak, Siejkowska 2003).

\section{Poczucie bezpieczeństwa a cechy demograficzno-społeczne}

Wyniki badań ankietowych są częściowo prezentowane w odniesieniu do cech demograficzno-społecznych respondentów, np.: wieku, płci, wykształcenia. Poczucie bezpieczeństwa ludzi młodych, którzy są najbardziej narażeni na zjawisko przestępczości jest wysokie (Guzik 2000b; Bogacka 2012), a osób powyżej 60. roku życia, stanowiących najmniej zagrożoną grupę - niskie (Guzik 2000b; Bogacka 2012; Mordwa 2013).

Biorąc pod uwagę płeć, mężczyźni odczuwają większy strach przed przestępczością od kobiet, jednak często nie ujawniają swojej prawdziwej opinii w badaniach ankietowych z powodu chęci podtrzymania istniejących $\mathrm{w}$ społeczeństwie stereotypów (Bogacka 2009, 2012). W swojej pracy S. Mordwa (2013) podejmuje 
ciekawe zagadnienie paradoksu strachu: młode kobiety rzadko deklarują strach przed nocnymi spacerami mimo słabej znajomości sąsiadów, niepewności w poruszaniu się po okolicy i słabych zabezpieczeń.

Warto jednak zwrócić uwagę, że wyniki wszystkich badań nie są jednakowe. Badania J. Kotusa (2005) ujawniły, że ani płeć, ani wiek nie różnicowały oceny poczucia bezpieczeństwa w obszarach najbliższych (sąsiedztwie) za dnia.

Wykształcenie również rzutuje na poczucie bezpieczeństwa. Z badań S. Mordwy (2013) wynika, że im wyższe wykształcenie, tym większe ludzie odczuwają poczucie bezpieczeństwa. Z kolei osoby z wykształceniem średnim i zasadniczym zawodowym cechują wyższe oceny ryzyka fizycznego ataku i ryzyka wiktymizacji (Mordwa 2013).

\section{Podsumowanie}

Prace dotyczące poczucia bezpieczeństwa mają swoje ważne miejsce w polskiej geografii przestępczości. Posiadają one dużą wagę związaną z tym, że „przestępczość i poczucie zagrożenia przestępczością w znaczny sposób wpływają na poziom i jakość życia ludzi. Z tego punktu widzenia większe znaczenie mają wyobrażenia ludzi odnośnie przestępczości i jej rozmieszczenia niż stan faktyczny" (Guzik 2000a: 201). Dokonany w pracy przegląd wybranych wyników badań zawartych w polskich publikacjach dotyczących poczucia bezpieczeństwa człowieka $\mathrm{w}$ przestrzeni miasta to potwierdza. Zagadnienie poczucie bezpieczeństwa jest stosunkowo często przedmiotem szczegółowych analiz. Każda z omawianych w tej pracy kwestii, ze względu na znaczną złożoność, może być tematem szerszych rozważań.

\section{LITERATURA}

Biderman E., 1995, Postrzeganie i ocena elementów przestrzeni miasta Poznania przez jego mieszkańców, Kronika Miasta Poznania, nr 1.

Bogacka E., 2009, Przestępczość w Poznaniu, Biuletyn Instytutu Geografii Społeczno-Ekonomicznej i Gospodarki Przestrzennej UAM, Seria Rozwój Regionalny i Polityka Regionalna, 6, s. 87-100.

Bogacka E., 2011, Wspótczesny dorobek światowych i polskich badań przestrzennych aspektów przestępczości, [w:] Korenik S., Przybyła Z. (red.), Gospodarka przestrzenna XXI wieku - nowe wyzwania, Prace Naukowe Uniwersytetu Ekonomicznego we Wrocławiu, nr 152, Wydawnictwo Uniwersytetu Ekonomicznego we Wrocławiu, Wrocław, s. 13-24.

Bogacka E., 2012, Struktura przestrzenna i czynniki przestępczości na obszarze nadgranicznym Polski z Niemcami, Bogucki Wydawnictwo Naukowe, Poznań.

Bogacka E., Siniecka A., 2016, Poczucie bezpieczeństwa mieszkańców miasta. Przykład Poznania, Rozwój Regionalny i Polityka Regionalna, 33, s. 57-71. 
Cichocki R., Podemski K., 1998, Życie w Poznaniu 1997. Mieszkańcy Poznania o swoim mieście, Wydawnictwo Ankieter Badania Rynkowe i Społeczne, Poznań.

Czarnecki B., Siemiński W., 2004, Kształtowanie bezpiecznej przestrzeni publicznej, Difin, Warszawa.

Czyż T., 1996, Issues in Social Geography, [w:] Chojnicki Z. (red.), Contemporary Problems of Polish Geography, Bogucki Wydawnictwo Naukowe, Poznań, s. 57-67.

Dolata M., Kotus J., 2004, Społeczne naznaczanie obszarów miasta, [w:] Jażdżewska I. (red.), Zróżnicowanie warunków życia ludności w mieście, Konwersatorium Wiedzy o Mieście, Łódź, s. 245-256.

Dolata M., Kotus J., 2006, Social Production of Urban Space. A Case Study of 'bad'Areas in Poznań, „Geographia Polonica”, 29(2), s. 5-22.

Frieske K., 2007, Przestępczość w Polsce na przełomie stuleci. Stereotypy i realia, [w:] Marody M. (red.), Wymiary życia społecznego. Polska na przełomie XX i XXI wieku, Wydawnictwo Naukowe Scholar, Warszawa, s. 212-240.

Guzik R., 2000a, Przestępczość w przestrzeni miejskiej Krakowa w wyobrażeniach jego mieszkańców, [w:] Jażdżewska I. (red.), Miasto postsocjalistyczne-organizacja przestrzeni miejskiej i jej przemiany, Konwersatorium Wiedzy o Mieście, Łódź, s. 201-204.

Guzik R., 2000b, Przestrzenny obraz przestępczości w prasie krakowskiej, [w:] Domański B. (red.), Studia nad rozwojem lokalnym i regionalnym, Prace Geograficzne, Instytut Geografii UJ, 106, Kraków, s. 197-216.

Jabkowski P., 2005, Bezpieczeństwo publiczne i zagrożenie przestępczościa, [w:] Cichocki R. (red.), Wskaźniki jakości życia mieszkańców Poznania, t. 1, Studia nad jakością życia, Wydawnictwo Naukowe UAM, Poznań, s. 135-162.

Jałowiecki B., 2000, Społeczna Przestrzeń Metropolii, Wydawnictwo Naukowe Scholar, Warszawa, s. 185-190.

Kotus J., 2005, Spoteczne dylematy w przestrzeni miejskiej, Bogucki Wydawnictwo Naukowe, Poznań.

Libura H., 1990, Percepcja przestrzeni miejskiej, Rozwój Regionalny, Rozwój Lokalny, Samorząd Terytorialny, Warszawa.

Maik W., 1995, Socio-spatial analysis of crime and delinquency. A case study of Toruń, [w:] Gałczyńska B., Węcławowicz G. (red.), Urban and regional issues in geographical research in Poland and Italy, Proceedings of the Seventh Polish-Italian Geographical Seminar, Conference Papers Nr 24, IGiPZ PAN, Warszawa, s. 91-98.

Marcińczak S., Siejkowska A., 2003, Percepcja miejsc niebezpiecznych $w$ Lodzi, [w:] Jażdżewska I. (red.), Funkcje metropolitalne $i$ ich rola $w$ organizacji przestrzeni, Konwersatorium Wiedzy o Mieście, Wydawnictwo UŁ, Łódź, s. 203-208.

Mordwa S., 2011, Poczucie bezpieczeństwa w Łodzi. Przykład badań mieszkańców osiedli mieszkaniowych, [w:] Dzieciuchowicz J. (red.), Współczesne przemiany środowiska mieszkaniowego-wybrane problemy, „Space-Society-Economy, 10, Department of Spatial Economy and Spatial Planning, Łódź, s. 181-196.

Mordwa S., 2012, Poczucie bezpieczeństwa w centrach handlowych. Przykład badań opinii klientów Galerii Łódzkiej i Manufaktury w Lodzi, „Acta Universitatis Lodziensis. Folia Geographica Socio-Oeconomica", 12, s. 163-187.

Mordwa S., 2013, Przestępczość i poczucie bezpieczeństwa w przestrzeni miasta. Przykład Łodzi, Wydawnictwo Uniwersytetu Łódzkiego, Łódź. 
Pain R., 2000, Place, Social Relations and the Fear of Crime: A Review, „Progress in Human Geography", 24(3), s. 365-387.

Piasecka K., 2015, Przestępczość i poczucie bezpieczeństwa $w$ Poznaniu $w$ ujęciu społeczno-przestrzennym, Praca magisterska napisana na Wydziale Nauk Geograficznych i Geologicznych UAM w Poznaniu pod kierunkiem dr Artura Bajerskiego.

Rydz E., Szymańska W., 2007, Waloryzacja przestrzeni miejskiej pod względem atrakcyjności mieszkaniowej i poczucia bezpieczeństwa średnich miast Pomorza, [w:] Madurowicz M. (red.), Percepcja wspótczesnej przestrzeni miejskiej, Instytut Geografii Społeczno-Ekonomicznej i Gospodarki Przestrzennej Wydziału Geografii i Studiów Regionalnych Uniwersytetu Warszawskiego, Warszawa, s. 331-341.

Tseloni A., Osborn D.R., Trickett A., Pease K., 2002, Modelling propert crime using the British Crime Survey. What have we learnt?, „British Journal of Criminology”, 42, s. 109-128.

Walentynowicz-Moryl K., Luczys P., 2012, Społeczna mapa miasta $w$ perspektywie obszarów granicznych. Pilotaż projektu badawczego w Poznaniu, [w:] Brzezińska A., Chwieduk A. (red.), Miasto Poznań w perspektywie badań interdyscyplinarnych, TIPI, Wielichowo.

Znaniecki F., Ziółkowski J., 1984, Czym jest dla ciebie miasto Poznań?, PWN, Warszawa -Poznań.

\section{HUMAN SECURITY IN THE CITY AS A RESEARCH ISSUE}

Abstract The article has a character of the review and concerns Polish publications on human security in the city. It begins with distinction of research directions in crime geography and the review of definitions of the sense of security. Next, selected Polish publications on the human security in the city and their results are presented. The following issues are discussed in the paper: 1) good and bad neighborhoods as a spatial stereotypes, 2) a sense of security vs. the type of building area, 3) a sense of security in the public places, 4) a sense of security in the neighborhood, 5) a sense of security vs. time of day, and 6) a sense of security vs. socio-demographic characteristics.

Keywords Sense of security, crime geography, city, Poland.

\section{Dr Emilia Bogacka \\ Zakład Gospodarki Przestrzennej} Instytut Geografii Społeczno-Ekonomicznej i Gospodarki Przestrzennej Wydział Nauk Geograficznych i Geologicznych Uniwersytet im. Adama Mickiewicza w Poznaniu e-mail: ebogacka@amu.edu.pl 